\title{
Ethics and genetics in China: an inside story
}

$\mathrm{Y}$ our editorial ${ }^{1}$ provided a thoughtful and informative overview of widespread concerns regarding eugenic legislation in China and elsewhere. However, one statement in this editorial _ " "... in the face of eugenic law, the genetical is political" - is likely to remind Chinese geneticists of their historical nightmare, in which so-called politics interfered with genetics research. For example, in the 1950 s, when China allied itself with the Soviet Union, the mendelian and Morgan schools of genetics from the West were criticized, while the Lysenko school of genetics from the USSR was in favour. During the 'Cultural Revolution' (1966-1976), the study of genetics whether influenced by Western or Soviet thought-was ridiculed and most Chinese geneticists lost their jobs. This may in part explain why the voice of Chinese geneticists on ethical, legal and social issues relating to genetics research and practice in Chinaincluding Chinese eugenics law-has hardly been heard until recently ${ }^{2,3}$.

China is a country of great contrasts. It has the world's largest population and yet a relative dearth of natural resources per capita. It has a long history and rich culture yet an uneven education system with 150 million illiterate and semi-illiterate people. It has the fastest-growing economy yet has stayed in the socialist political system of one-party rule. Its territory is vast, with the level of development varying greatly from region to region. Traditional Chinese moral values, which are profoundly affected by Confucianism, Taoism and Buddhism, emphasize the importance of loyalty, filial piety, humanity and brothership. Marxism and Mao Zedong's thought have informed mainstream ideology in China for nearly half a century, an ideology that regards each person as a component of the whole society and advocates that the individual's interest should be subordinated to the interests of the nation. A national survey shows that most Chinese geneticists would agree to disclose genetic information to relatives at risk, and to permit institutional third parties to access stored DNA without consent ${ }^{2,3}$, perhaps because Chinese geneticists hold strong social views regarding the use of genetic information, which they think important not only to the patient but also to society (X. Mao \& D.C. Wertz, in press) - clearly a viewpoint that is unacceptable in most European-based societies, including the United States ${ }^{4}$.

An international survey exploring ethics and genetics in 37 nations ${ }^{5}$ shows that geneticists in many countries describe their major goal as the prevention of genetic disorders. Most geneticists in China, Cuba, Egypt, India, Mexico, Peru, Greece, Poland, Russia, Spain and Turkey agreed that "an important goal of genetic counselling is to reduce the number of deleterious genes in the population". Improving the gene pool by any means is generally considered by Western geneticists to be a eugenic goal, while only Chinese geneticists openly declared "improvement of the population quality" and "furtherance of eugenic principles" as the major goal of genetics.
China has a paternalistic tradition that influences Chinese geneticists as reflected by a national survey that shows that most would prefer to practice directive counselling. The concept of non-directiveness and the particular reasons for being nondirective have only very slowly gained credibility in Western genetics over the last 15 or 20 years; it is hard at this stage to say whether geneticists practising in other cultures, such as China's, will eventually move in the same direction, or whether there really are fundamental societal differences as opposed to just differences of timing (M. Bobrow, pers. comm.).

It is clear that one must be careful transferring the moral and social views of one society onto another. Constructive dialogue is required to understand and clarify how societal mores impact genetic practice. The 1998 International Congress of Genetics in Beijing would hopefully provide an opportunity for geneticists to educate each other.

\section{Xin Mao}

Division of Genetics, Department of Psychiatry, West China University of Medical Sciences, Chengdu 610041, Sichuan, People's Republic China. Present address: Section of Molecular Carcinogenesis, Haddow Laboratories, Institute of Cancer Research, 15 Cotswold Road, Sutton. Surrey SM2 SNG, UK.

\footnotetext{
1. Editorial. Nature Genet. 15, 1-2 (1997).

2. Mao, X. Nature 384, 404 (1996)

3. Mao, X. Lancet 349, 139 (1997)

4. Reilly, P.R. et al. Nature Genet. 15, 16-20 (1997)

5. Wertz, D.C. \& Fletcher, J.C. Clin. Genet. 43, 104-110 (1993).
} 